\title{
Uloga nacionalnog registra u zbrinjavanju djece oboljele od kroničnih upalnih bolesti crijeva
}

\author{
Lana Ivković, Iva Hojsak, Tena Trbojević, Sanja Kolaček*
}

\begin{abstract}
Kroničnim upalnim bolestima crijeva u djece, za razliku od odraslih, svojstven je teži tijek i prošireniji oblik bolesti te negativan utjecaj na rast i razvoj. U posljednjih nekoliko desetljeća zamijećen je trend porasta incidencije kroničnih upalnih bolesti crijeva, najviše na račun Crohnove bolesti. Uzimajući u obzir sve navedeno, ali i činjenicu da se upalne bolesti crijeva u djece pojavljuju u razdoblju njihovog ubrzanog rasta i razvoja, svi pedijatrijski bolesnici iziskuju dugoročno praćenje koje je moguće jedino putem nacionalnog registra. U ovom preglednom članku raspravljamo o ulogama, ciljevima i metodama rada nacionalnih registara, koji imaju za cilj praćenje različitih varijabli u djece s kroničnim upalnim bolestima crijeva, ali naglašavamo i važnost osnivanja takvog registra u Republici Hrvatskoj.
\end{abstract}

Ključne riječi: upalne bolesti crijeva; registri; dijete; Hrvatska

\section{UVOD}

Kronične upalne bolesti crijeva zahvaćaju gastrointestinalni sustav, obilježene su relapsirajućim tijekom, a uključuju Crohnovu bolest, ulcerozni i nedeterminirani kolitis. Bolest koja počinje u dječjoj dobi u mnogočemu se razlikuje od one u odrasloj, ne samo time što je agresivnija pa zahvaća veći dio probavnog sustava u usporedbi s odraslim bolesnicima $(1,2,3)$, nego i tijekom vremena mijenja fenotip iz blažeg u teži oblik (1). Samim tim liječenje djece se bitno razlikuje od liječenja odraslih bolesnika.

Najznačajnija osobitost upalnih bolesti crijeva u dječjoj dobi je zaostatak u rastu i spolnom razvoju koji negativno utječe na psihosocijalni razvoj djece, a time i na kakvoću njihovih života (4).

Zbog velike varijabilnosti i brojnih specifičnosti same dječje populacije i širokog spektra obilježja bolesti, jedini način za dugoročno sustavno praćenje oboljele djece je putem registra oboljelih, kojima je osnovna zadaća sustavno i kontinuirano prikupljanje i pohranjivanje podataka o oboljelima, koji služe kao osnova za planiranje i provedbu daljnjih istraživanja, ali i kliničko praćenje bolesnika.

Cilj nam je stoga ovim radom u početnom dijelu istaknuti osobitosti kroničnih upalnih bolesti crijeva u djece, a potom prikazati obilježja, uloge i ciljeve nacionalnih registara za djecu oboljelu od kroničnih upalnih bolesti crijeva, te posebno istaknuti kliničku, ali i znanstvenu važnost utemeljenja takvog registra u našoj državi.

\section{OSOBITOSTI KRONIČNIH UPALNIH BOLESTI CRIJEVA U DJECE}

Djeca oboljela od kroničnih upalnih bolesti crijeva najčešće imaju prošireniji i teži oblik bolesti te drukčiji klinički tijek u odnosu na odrasle (5). Budući da se otprilike 1/4 - 1/3 svih bolesnika dijagnosticira u dječjoj i adolescentnoj dobi (6), upalne bolesti crijeva u djece veliki su problem na koji se pravodobnom i adekvatnom intervencijom može znatno utjecati. lako se najčešće dijagnosticiraju u kasnom djetinjstvu i adolescenciji, mogu se pojaviti u bilo kojoj pedijatrijskoj dobi, uključujući i dojenačku (7). Tijekom posljednjih pedesetak godina u cijelom je svijetu zamijećen porast inci* Klinika za dječje bolesti Zagreb, Klinika za pedijatriju, Klaićeva 16, 10000
Zagreb

\section{Adresa za dopisivanje:}

Lana Ivković, dr. med., Klinika za dječje bolesti Zagreb, Klinika za pedijatriju, Klaićeva 16, 10000 Zagreb, e-mail: lananjavro@yahoo.com

Primljeno/Received: 29. 4. 2015., Prihvaćeno/Accepted:21. 7. 2015. 
dencije kroničnih upalnih bolesti crijeva u djece, uglavnom na račun Crohnove bolesti, dok incidencija ulceroznog kolitisa stagnira $(1,8)$. Kao mogući uzroci navode se dosad još nepoznati okolišni čimbenici. Procjenjuje se da je ukupna incidencija kroničnih upalnih bolesti crijeva u djece oko 7/100 000 (1), a učestalost je veća u razvijenim zemljama sjeverne polutke (9). Crohnova se bolest najčešće prezentira bolovima u trbuhu, a ulcerozni kolitis rektalnim krvarenjem i proljevom $(10,11,12,13)$. Osim crijevnim, manifestiraju se i izvancrijevnim (ekstraintestinalnim) simptomima, koji se pri postavljanju dijagnoze nalaze u 6-20\% oboljele djece $(2,11$, $14,15)$. Najčešće je riječ o artralgiji, aftoznom stomatitisu i nešto rjeđe artritisu (11, 14-16). Najčešća kožna manifestacija, nodozni eritem, pojavljuje se češće u Crohnovoj bolesti $(14,16)$, a bolesti jetre, sklerozirajući kolangitis i autoimuni hepatitis u ulceroznom kolitisu (11, 14-16). Najznačajnija osobitost bolesti u dječjoj dobi je zastoj u rastu koji se može javiti kao prvi simptom, odnosno biti prisutan pri postavljanju dijagnoze, ali može nastati i kao posljedica dugotrajne bolesti i primijenjene terapije. Značajniji zastoj u rastu nalazi se u Crohnovoj bolesti $(12,17)$. Radi što bolje procjene prognoze bolesti, odluke o uvođenju najprikladnije terapije te izrade dijagnostičkih kriterija, nužna je pravilna klasifikacija fenotipa bolesti. Zbog svih osobitosti bolesti u dječjoj dobi, koje navodimo u tablici 1 (18), godine 2011. tiskana je Pariška klasifikacija kroničnih upalnih bolesti crijeva (19), koja je pedijatrijska modifikacija trenutno važeće Montrealske klasifikacije (20). Najčešći fenotip Crohnove bolesti prema Montrealskoj klasifikaciji je ileokolični oblik bolesti (L3), a ulceroznog kolitisa ekstenzivni kolitis (E3) $(2,12,13$, 21-25), odnosno prema Pariškoj klasifikaciji pankolitis (E4), kojim se zahvaćeno područje širi i proksimalno od hepatične fleksure $(3,17)$. U mlađe djece oboljele od Crohnove bolesti češće je zahvaćeno debelo crijevo, a u adolescenata terminalni ileum $(2,25)$, dok je u ulceroznom kolitisu nađeno značajno manje proktitisa u mlađe djece nego u adolesce-

TABLICA 1. Osobitosti bolesti u djece

\begin{tabular}{|c|c|}
\hline IBD u dječjoj dobi & IBD u odrasloj dobi \\
\hline • viša učestalost CD-a & • jednaki udio CD-a i UC-a \\
\hline $\begin{array}{l}\text { - prošireni i teži oblik te promjenjivi } \\
\text { tijek }\end{array}$ & • češće limitirana bolest \\
\hline $\begin{array}{l}\text { • češće zahvaćen gornji dio } \\
\text { probavnog sustava }\end{array}$ & $\begin{array}{l}\text { - rjeđe zhavaćen gornji dio } \\
\text { probavnog sustava }\end{array}$ \\
\hline - ograničeno trajanje bolesti & • duže trajanje bolesti \\
\hline $\begin{array}{l}\text { • zastoj u rastu i/ili zakašnjeli } \\
\text { pubertet }\end{array}$ & $\begin{array}{l}\text { - upotreba steroida u indukciji } \\
\text { remisije CD-a }\end{array}$ \\
\hline $\begin{array}{l}\text { - uloga enteralne prehrane u } \\
\text { indukciji remisije CD-a }\end{array}$ & $\begin{array}{l}\text { • veća učestalost operativnih } \\
\text { zahvata }\end{array}$ \\
\hline \multicolumn{2}{|l|}{$\begin{array}{l}\text { • manja učestalost operativnih } \\
\text { zahvata }\end{array}$} \\
\hline
\end{tabular}

nata $(24,25)$. Perianalna bolest u djece oboljele od Crohnove bolesti nalazi se u njih $10 \%$ pri postavljanju dijagnoze (26). Prema revidiranim Porto kriterijima iz 2014. godine dijagnoza upalnih bolesti crijeva postavlja se na temelju anamneze, kliničke slike, laboratorijskih nalaza, slikovnog prikaza tankog crijeva, ezofagogastroduodenoskopije i ileokolonoskopije s patohistološkom analizom multiplih uzoraka sluznice iz svih dijelova probavnog trakta. Metoda izbora u slikovnoj dijagnostici je enterografija magnetskom rezonancijom (MR enterografija), koja može dijagnosticirati upalne promjene u crijevnom zidu, ali i komplikacije bolesti kao što su fistule, apscesi i stenoze. U slučaju nemogućnosti izvođenja MR enterografije, kao alternativa se preporuča endoskopija videokapsulom, koja je posebno bitna u dijagnostici Crohnove bolesti. Od izrazite je važnosti prethodno isključenje infektivnih uzroka upale crijevne sluznice, iako identifikacija patogena ne isključuje dijagnozu upalne bolesti crijeva, jer prva epizoda ili egzacerbacija bolesti može biti potaknuta crijevnom infekcijom. Provođenjem uniformnog dijagnostičkog postupnika, koji uključuje gornju endoskopiju, utvrđena je značajna zahvaćenost gornjeg dijela probavnog sustava $(2,3,12,27)$ u čak $22-31 \%$ oboljelih od Crohnove bolesti $(2,27)$, pa čak i u ulceroznom kolitisu (3). U nedavno tiskanim ECCO (engl. European Crohn's and Colitis Organisation) / ESPGHAN (engl. European Society for Paediatric Gastroenterology, Hepatology and Nutrition) smjernicama za liječenje Crohnove bolesti (28) i ulceroznog kolitisa u djece (29), terapija prvog izbora u indukciji remisije Crohnove bolesti je isključiva enteralna prehrana, dok se za održavanje remisije preporuča uporaba imunomodulatora (azatioprin/6-merkaptopurin, metotreksat). Za razliku od odraslih bolesnika, oralni kortikosteroidi primjenjuju se jedino kad isključiva enteralna prehrana nije opcija, a zbog utjecaja na rast, nikako se ne bi trebali rabiti kao terapija održavanja. U liječenju ulceroznog kolitisa lijek prvog izbora za indukciju i održavanje remisije su aminosalicilati, a u djece u kojih se remisija ne može postići terapijom aminosalicilatima, opravdana je primjena oralnih kortikosteroida. Biološka se terapija preporuča za indukciju i održavanje remisije u djece s kronično aktivnom bolešću refrakternom na primjenu imunomodulatornih lijekova, kao i za indukciju remisije u djece s aktivnom bolešću koja je rezistentna na primjenu enteralne prehrane, kortikosteroidne terapije te kombinacije lokalne i sistemske aminosalicilatne terapije u djece s ulceroznim kolitisom. Učestalost kirurškog liječenja u prve dvije godine nakon dijagnoze iznosi 4-6 \% (17, 30, 31), ali već nakon toga kirurško će liječenje biti nužno u 15\% djece (16).

S obzirom na zamijećeni porast incidencije, specifična obilježja bolesti u djece, prvenstveno brzu progresiju i zahvaćenost velikih površina probavnog sustava, ali i činjenicu da se upalne bolesti crijeva najčešće pojavljuju u razdoblju kritičnom za djetetov rast i razvoj, oboljelu je djecu potreb- 
no dugoročno i sustavno pratiti, što je moguće jedino putem nacionalnog registra.

\section{REGISTRI I NJIHOVA PRIMJENA}

Registar oboljelih definira se kao organizirani sustav u koji se unose prospektivno prikupljeni, unaprijed određeni podatci o specifičnoj populaciji bolesnika, a služi unaprijed predodređenoj znanstvenoj, kliničkoj ili pravnoj svrsi (32). Namjena im je vrlo raznolika, ali svima je zajedničko da su prvenstveno usmjereni na bolje razumijevanje bolesti, a time i na bolje zbrinjavanje bolesnika. Primjenjuju se $u$ ispitivanju etiologije, incidencije i prevalencije bolesti, socio-demografskog profila bolesnika, određivanju fenotipa bolesti pri njezinoj dijagnozi, kliničkom praćenju, mjerenju uspješnosti dijagnostičkih postupaka i terapijskih metoda, praćenju provođenja kliničkih smjernica pri odabiru terapije, kakvoći tih smjernica, ali i praćenju rada ustanova.

Osim što su registri izvor klinički relevantnih podataka za bolesnike, ali i za liječnike i znanstvenike, pružaju podatke o populacijama koje se inače rjeđe proučavaju u kliničkim ispitivanjima, kao što su djeca, stariji ljudi ili trudnice (32). Mogu biti osnovani unutar jedne ustanove, više njih ili na nacionalnoj, odnosno internacionalnoj razini. Nacionalni registri služe za otkrivanje i opis nacionalnih obilježja bolesti, njihovih razlika u pojedinoj državi te za izradu nacionalnih dijagnostičkih i terapijskih smjernica. Internacionalni registri objedinjuju i uspoređuju podatke i iskustva različitih zemalja, prate globalne trendove u pojavnosti bolesti, ali i učinkovitost dijagnostičkih i terapijskih smjernica te dosljednost u njihovoj primjeni. Što je područje koje registar pokriva veće, to su podatci koje iz njega možemo iščitati relevantniji, odnosno sličniji stvarnom stanju na nekom području. Registre uglavnom stvaraju i vode istraživači (engl. research-generated), no u novije vrijeme sve je više registara što ih iniciraju bolesnici (engl. patient-powered), u kojima oni i članovi njihovih obitelji „osnažuju “ registar kontroliranjem prikupljanja podataka i sudjelovanjem u planu istraživanja ili njegovim širenjem. Smatra se da tako dobiveni podatci mogu bolje opisati bolest i pomoći bolesniku i njegovoj obitelji u donošenju određenih odluka (33). No loše su strane mali broj bolesnika dovoljno osviještenih i educiranih za sudjelovanje te činjenica da su tako dobiveni podatci vrlo podložni pogrješkama iz čitavog niza razloga. Unatoč tome, patient-powered registri značajno su pridonijeli istraživanjima o potrebama bolesnika i njihovih obitelji (33). No neovisno o tome tko upravlja registrom, da bi on bio učinkovit, mora biti pomno osmišljen, s unaprijed određenim ciljevima i jasno definiranim metodama prikupljanja i analiziranja podataka.

Dobrobit osnivanja registra prepoznali su i pedijatrijski gastroenterolozi. U prilog tome govori činjenica da je u po- sljednjih 15-ak godina osnovano mnogo pedijatrijskih registara za kronične upalne bolesti crijeva na području Sjedinjenih Američkih Država (SAD) i Kanade, Japana i brojnih zemalja Europe, koje zajedno s njihovim osnovnim obilježjima navodimo u tablici 2.

Radi boljeg upoznavanja pedijatrijskog fenotipa bolesti u trenutku postavljanja dijagnoze u Europi 2004. godine je osnovan Europski registar za djecu oboljelu od kroničnih upalnih bolesti crijeva (EUROKIDS Registry) $(2,3,5,34)$. Referentni centar za dječju gastroenterologiju i prehranu Klinike za dječje bolesti Zagreb, suosnivač je tog registra, a ujedno i jedini centar u Republici Hrvatskoj koji u njemu sudjeluje. U EUROKIDS registar uključena su 44 centra iz 18 zemalja Europe i Izraela. Dosad su prikupljeni podatci o više od 4300 bolesnika. Ciljevi ovog registra su: upoznati fenotip Crohnove bolesti (2) i ulceroznog kolitisa (3) u djece u trenutku kliničke prezentacije, izraditi dijagnostički postupnik (35) te na temelju praćenja njegove primjene, prema potrebi, revidirati slijed i vrstu dijagnostičkih postupaka (36). Štoviše, uloga je EUROKIDS registra objedinjavanje terapijskih iskustava te kontrolirano ispitivanje novih terapijskih i dijagnostičkih postupaka na relevantnom broju oboljele djece.

No ono što ovaj registar ne može, a što mu nije ni cilj, to je odrediti nacionalne karakteristike bolesti, nacionalnu incidenciju i prevalenciju i osigurati bolju povezanost centara te ujednačiti dijagnostički i terapijski plan na nacionalnoj razini. Stoga većina razvijenih zemalja utemeljuje i nacionalne registre.

\section{DOSADAŠNJA ISKUSTVA S NACIONALNIM REGISTRIMA}

Pretragom literature pronašli smo 18 relevantnih registara koji su poslužili za istraživanja širokog spektra problematike vezane za kronične upalne bolesti crijeva u djece. Najveći registri postoje u SAD-u, no mnogobrojni su i u zemljama Europe.

Većina nacionalnih registara osnovana je prvenstveno radi određivanja nacionalne incidencije i prevalencije bolesti, ali i drugih epidemioloških podataka. Kako bismo što vjernije prikazali potrebu za osnivanjem nacionalnih registara, u tablici 3 navodimo obilježja kroničnih upalnih bolesti crijeva koja in čine pogodnima za praćenje putem nacionalnih registara, a koja će ukratko biti opisana u daljnjem slijedu teksta.

\section{INCIDENCIJA}

Budući da podatci svjetske literature govore u prilog trendu porasta incidencije kroničnih upalnih bolesti crijeva u djece, prvenstveno na račun Crohnove bolesti, ne čudi činjenica da je najčešće proučavan parametar baš incidencija bolesti, 
TABLICA 2. Svjetski registri za oboljele od upalnih bolesti crijeva i njihove karakteristike

\begin{tabular}{|c|c|c|c|c|c|}
\hline Naziv/Država & $\begin{array}{l}\text { Godina } \\
\text { osnivanja }\end{array}$ & Populacija & Slučajevi & Broj ispitanika & Područje istraživanja \\
\hline $\begin{array}{l}\text { EUROKIDS } \\
\text { Registry/17 zemalja Europe } \\
\text { i Izrael ( } 44 \text { centra) }(2,3,5,34)\end{array}$ & 2004. & $\begin{array}{l}\text { Djeca do } 18 \\
\text { godina starosti }\end{array}$ & Incidentni & $>2000$ & $\begin{array}{l}\text { - Fenotip } \\
\text { - Provođenje dijagnostičkog } \\
\text { postupka prema Porto kriterijima }\end{array}$ \\
\hline $\begin{array}{l}\text { Pediatric IBD } \\
\text { Consortium } \\
\text { Registry/SAD (6 centara) } \\
(7,15,25,41)\end{array}$ & 2000. & $\begin{array}{l}\text { Djeca do } 18 \\
\text { godina starosti }\end{array}$ & $\begin{array}{l}\text { Incidentni i } \\
\text { prevalentni }\end{array}$ & $>1600$ & $\begin{array}{l}\text { - Obiteljska povezanost } \\
\text { - Rasne/etničke razlike } \\
\text { - Fenotip } \\
\text { - Izvancrijevne manifestacije }\end{array}$ \\
\hline $\begin{array}{l}\text { National Registry/ Wisconsin, } \\
\text { SAD (10) }\end{array}$ & 2000. & $\begin{array}{l}\text { Djeca do } 18 \\
\text { godina starosti }\end{array}$ & Incidentni & 199 & $\begin{array}{l}\text { - Incidencija } \\
\text { - Etničke/rasne razlike } \\
\text { - Obiteljska povezanost } \\
\text { - Klinička prezentacija }\end{array}$ \\
\hline $\begin{array}{l}\text { Pediatric National } \\
\text { IBD Register/Italija } \\
\text { (40 centara) }(11)\end{array}$ & 1996. & $\begin{array}{l}\text { Djeca do } 18 \\
\text { godina starosti }\end{array}$ & $\begin{array}{l}\text { Incidentni i } \\
\text { prevalentni }\end{array}$ & $>1500$ & $\begin{array}{l}\text { - Incidencija } \\
\text { - Obiteljska povezanost } \\
\text { - Klinička prezentacija } \\
\text { - Vrijeme do postavljanja dijagnoze } \\
\text { - Ekstraintestinalne manifestacije }\end{array}$ \\
\hline $\begin{array}{l}\text { Registry of Pediatric } \\
\text { Patients Diagnosed } \\
\text { With Crohn's Disease } \\
\text { (BELCRO)/Belgija } \\
\text { ( } 23 \text { centra) (12) }\end{array}$ & 2008. & $\begin{array}{l}\text { Djeca do } 18 \\
\text { godina starosti }\end{array}$ & $\begin{array}{l}\text { Incidentni i } \\
\text { prevalentni }\end{array}$ & $>250$ & $\begin{array}{l}\text { - Obiteljska povezanost } \\
\text { - Klinička prezentacija } \\
\text { - Zastoj u rastu } \\
\text { - Vrijeme do postavljanja dijagnoze } \\
\text { - Fenotip }\end{array}$ \\
\hline $\begin{array}{l}\text { German- Language } \\
\text { Pediatric IBD } \\
\text { Registry (CEDATA) } \\
\text { / Njemačka i Austrija } \\
\text { (53 centra) (13) }\end{array}$ & 2004. & $\begin{array}{l}\text { Djeca do } 18 \\
\text { godina starosti }\end{array}$ & $\begin{array}{l}\text { Incidentni i } \\
\text { prevalentni }\end{array}$ & $>2000$ & $\begin{array}{l}\text { - Klinička prezentacija } \\
\text { - Zastoj u rastu } \\
\text { - Vrijeme do postavljanja dijagnoze } \\
\text { - Fenotip }\end{array}$ \\
\hline $\begin{array}{l}\text { Pediatric } \\
\text { Inflammatory Bowel } \\
\text { Disease } \\
\text { Collaborative } \\
\text { Research Group } \\
\text { Registry/SAD i Kanada } \\
\text { (19 centara) }(14,26)\end{array}$ & 2002. & $\begin{array}{l}\text { Djeca do } 16 \\
\text { godina starosti }\end{array}$ & Incidentni & $>1000$ & $\begin{array}{l}\text { - Izvancrijevne manifestacije } \\
\text { - Pojava perianalne bolesti }\end{array}$ \\
\hline $\begin{array}{l}\text { Register of } \\
\text { Paediatric IBD } \\
\text { (RPBID)/Ujedinjeno Kraljevstvo } \\
\text { (50 centara) (16) }\end{array}$ & 1997. & Djeca & Incidentni & $>2000$ & $\begin{array}{l}\text { - Incidencija } \\
\text { - Obiteljska povezanost } \\
\text { - Ekstraintestinalne manifestacije } \\
\text { - Zastoj u rastu } \\
\text { - Vrijeme do postavljanja dijagnoze } \\
\text { - Prirodni tijek bolesti } \\
\text { - Kirurške intervencije }\end{array}$ \\
\hline $\begin{array}{l}\text { HUPIR } \\
\text { Registry/Mađarska } \\
\text { (27 ustanova) } \\
(17,27)\end{array}$ & 2007. & $\begin{array}{l}\text { Djeca do } 18 \\
\text { godina starosti }\end{array}$ & Incidentni & $>400$ & $\begin{array}{l}\text { - Incidencija } \\
\text { - Obiteljska povezanost } \\
\text { - Fenotip } \\
\text { - Ekstraintestinalne manifestacije } \\
\text { - Zastoj u rastu } \\
\text { - Dijagnostička vrijednost EGD } \\
\text { - Terapijske strategije } \\
\text { - Kirurške intervencije }\end{array}$ \\
\hline $\begin{array}{l}\text { SPIRIT } \\
\text { Registry/Španjolska } \\
(21)\end{array}$ & 1996. & $\begin{array}{l}\text { Djeca do } 18 \\
\text { godina starosti }\end{array}$ & Incidentni & $>2000$ & $\begin{array}{l}\text { - Incidencija } \\
\text { - Fenotip } \\
\text { - Sjeverno - južni gradijent }\end{array}$ \\
\hline $\begin{array}{l}\text { Danish Crohn Colitis } \\
\text { Database/Danska } \\
(22,30)\end{array}$ & 2001. & $\begin{array}{l}\text { Djeca do } 15 \\
\text { godina starosti }\end{array}$ & $\begin{array}{l}\text { Incidentni } \\
\text { i prevalentni }\end{array}$ & $>6000$ & $\begin{array}{l}\text { - Incidencija } \\
\text { - Fenotip } \\
\text { - Kirurške intervencije } \\
\text { - Pojava maligniteta } \\
\text { - Smrtnost }\end{array}$ \\
\hline $\begin{array}{l}\text { EPIMAD } \\
\text { Registry/sjeverna } \\
\text { Francuska }(23,38,43)\end{array}$ & 1988. & $\begin{array}{l}\text { Djeca } \\
\text { (do } 17 \text { godina } \\
\text { starosti) } \\
\text { i odrasli }\end{array}$ & Incidentni & $>18000$ & $\begin{array}{l}\text { - Incidencija } \\
\text { - Obiteljska povezanost } \\
\text { - Okolišni rizični čimbenici } \\
\text { - Geografske varijacije u fenotipu } \\
\text { - Vrijeme do postavljanja dijagnoze } \\
\text { - Prirodni tijek bolesti } \\
\text { - Pojava karcinoma } \\
\text { - Smrtnost }\end{array}$ \\
\hline
\end{tabular}


TABLICA 2. Svjetski registri za oboljele od upalnih bolesti crijeva i njihove karakteristike - nastavak

\begin{tabular}{|c|c|c|c|c|c|}
\hline Naziv/Država & $\begin{array}{l}\text { Godina } \\
\text { osnivanja }\end{array}$ & Populacija & Slučajevi & Broj ispitanika & Područje istraživanja \\
\hline $\begin{array}{l}\text { Japanese Nationwide } \\
\text { Inflammatory Bowel } \\
\text { Disease } \\
\text { Registry/Japan (24) }\end{array}$ & 1975. & $\begin{array}{l}\text { Djeca } \\
\text { (do } 16 \text { godina } \\
\text { starosti) } \\
\text { i odrasli }\end{array}$ & $\begin{array}{l}\text { Incidentni } \\
\text { i prevalentni }\end{array}$ & $>50000$ & $\begin{array}{l}\text { - Incidencija i prevalencija } \\
\text { - Obiteljska povezanost } \\
\text { - Usporedba fenotipa bolesti } \\
\text { u djece i odraslih }\end{array}$ \\
\hline $\begin{array}{l}\text { Ocean State Crohn's } \\
\text { and Colitis Registry } \\
\text { (OSCCAR)/Rhode } \\
\text { Island, SAD (37) }\end{array}$ & 2008. & Djeca i odrasli & Incidentni & $<100$ & $\begin{array}{l}\text { - Incidencija } \\
\text { - Identifikacija rizičnih čimbenika } \\
\text { - Prirodni tijek bolesti } \\
\text { - Ishodi bolesti }\end{array}$ \\
\hline $\begin{array}{l}\text { EXPERIENCE } \\
\text { Registry/Španjolska (39) }\end{array}$ & 1985. & $\begin{array}{l}\text { Djeca do } 18 \\
\text { godina starosti }\end{array}$ & Incidentni & 495 & - Incidencija \\
\hline $\begin{array}{l}\text { Drug } \\
\text { Reimbursement } \\
\text { Register i Drug } \\
\text { Purchase } \\
\text { Register/Finska (42) }\end{array}$ & 1994. & $\begin{array}{l}\text { Djeca do } 15 \\
\text { godina starosti }\end{array}$ & Incidentni & $>400$ & - Terapijske strategije \\
\hline $\begin{array}{l}\text { ImproveCareNow } \\
\text { /SAD ( } 24 \text { centra) } \\
\text { (44) }\end{array}$ & 2007. & Djeca & $\begin{array}{l}\text { Incidentni } \\
\text { i prevalentni }\end{array}$ & $>2500$ & $\begin{array}{l}\text { - Skrb za pacijente } \\
\text { - Ishodi bolesti } \\
\text { - Postotak uvedenih u remisiju }\end{array}$ \\
\hline $\begin{array}{l}\text { DEVELOP/SAD ( } 59 \\
\text { centara) i Kanada ( } 2 \\
\text { centra) (45) }\end{array}$ & 2007. & $\begin{array}{l}\text { Djeca do } 17 \\
\text { godina starosti }\end{array}$ & Incidentni & $>5000$ & $\begin{array}{l}\text { - Dugoročni klinički status } \\
\text { i sigurnost pacijenata nakon } \\
\text { primjene biološke i drugih oblika } \\
\text { terapije }\end{array}$ \\
\hline
\end{tabular}

\section{TABLICA 3. Osobitosti bolesti koje se najčešće prate u registrima}

\section{Razlike u incidenciji i prevalenciji}

Uloga okolišnih čimbenika u pojavnosti bolesti

Fenotipska obilježja bolesti

Provođenje dijagnostičkih i terapijskih smjernica - izrada nacionalnih algoritama

Praćenje bolesnika ( engl. long-term outcome)

odnosno njezin porast $(10,11,16,17,21,22,37-39)$. Najviši porast ukupne incidencije zabilježen je u Španjolskoj - u posljednjih 30-ak godina čak šesnaesterostruk $(21,39)$. lako je prema literaturi uglavnom zabilježen veći porast incidencije Crohnove bolesti $(10,17,21,22,38,39)$, podatci nisu konzistentni; npr. Italija bilježi značajan porast ulceroznog kolitisa (11). U Francuskoj je utvrđeno da učestalost Crohnove bolesti u ovom trenutku najviše raste u dobnoj skupini djece od 10-19 godina (40). Taj podatak zorno pokazuje vrijednost i važnost registra, jer ako učestalost bolesti raste $u$ jednoj određenoj dobnoj skupini, onda baš u tih bolesnika koje otkrivamo registrom treba tražiti čimbenike što pridonose kliničkom očitovanju bolesti. lako su rasne / etničke razlike u epidemiologiji djece još i sad nedovoljno dobro istražene, podatci iz jednog američkog registra pokazuju da je u djece afričko-američkog podrijetla češća pojava Crohnove bolesti nego drugih oblika upalnih bolesti crijeva, i to u starijoj dobi nego što je to u djece bijele rase (41). Usko vezan za incidenciju je fenomen sjeverno - južnog gradijenta pojavnosti bolesti, koji je opisan na razini svijeta, ali baš zbog podataka iz nacionalnih registara pronađen je i u samim državama, kao primjerice u Španjolskoj i Francuskoj $(21,23)$. Republika Hrvatska, kao zemlja vrlo specifičnog oblika i raznolikog podneblja, idealan je kandidat za proučavanje ovog fenomena.

\section{OBITELJSKA POVEZANOST}

Podatci o obiteljskoj povezanosti u registrima dosta variraju; od 3-4\% nađenih u Japanu (24), do 29\% slučajeva u SAD-u (25). Ipak, najveći broj istraživanja pokazuje da pozitivna obiteljska anamneza postoji u 10-12\% oboljelih, pretežito s istim oblikom kronične upalne bolesti crijeva (10-12, 16, 17, $24,38)$, te da je obrnuto proporcionalna s dobi djece (25).

\section{FENOTIP BOLESTI}

Osnovna zadaća pravilnog određivanja fenotipa bolesti je, uz izradu dijagnostičkih kriterija, bolje upoznavanje dugoročne prognoze bolesti. Registri i u ovom području imaju bitnu ulogu, jer su baš oni pridonijeli izradi Montrealske i Pariške klasifikacije. Iz njih smo saznali koji je najčešći fenotip bolesti pri postavljanju dijagnoze $(2,3,12,13,17,21-25)$, zatim da je fenotip u djece dobno ovisan $(2,24,25)$, a poslužili su i za opis novih, atipičnih oblika bolesti (3). Na temelju podataka o manjoj učestalosti proktitisa u mlađe djece postavljen je temelj za kasniji opis fenomena „poštede rektuma" (engl. rectal sparing) koji je EUROKIDS registar opisao kao jedan od atipičnih fenotipa ulceroznog kolitisa (3). 


\section{DIJAGNOZA}

Podatci iz registra služe i za nadgledanje pridržavanja dijagnostičkih protokola (2), za proučavanje njihove učinkovitosti $(2,27)$, dostupnosti dijagnostičkih pomagala i naprava $(2,12,27)$, za stjecanje novih spoznaja o kliničkim osobitostima bolesti te kako ih pouzdano dijagnosticirati klinički, radiološki i patohistološki. Zanimljiv je podatak dobiven iz EUROKIDS registra o južno - sjevernom gradijentu zahvaćenosti gornjeg dijela probavnog sustava, s većom pojavnošću u Izraelu i zemljama južne Europe (2).

\section{LIJEČENJE}

Podatci dobiveni iz registara pokazuju kako se kortikosteroidi primjenjuju sve manje, dok uporaba imunomodulatora raste, što je sukladno preporukama $(17,30,42)$, te da se smanjuje udio djece liječene kirurškim metodama (17, 30, 31). U Finskoj, gdje svi oboljeli od kronične upalne bolesti crijeva imaju pravo na naknadu dijela troškova za lijekove, podatci iz dvaju postojećih registara - Registar za refundaciju troškova lijekova (za identifikaciju oboljelih) i Registar kupnje lijekova (indikator uporabe lijekova) jasno predočuju načine liječenja i utrošak pojedinih lijekova u trenutku bolesnikova napuštanja bolnice (42).

\section{PRAĆENJE BOLESNIKA}

Najveća vrijednost registra je u mogućnosti dugoročnog praćenja bolesnika i ishoda njegove bolesti. Tako na temelju podataka iz registara osnovanih prije više godina sad imamo informacije o vjerojatnosti razvoja maligniteta u oboljelih (22) te o njihovom mortalitetu $(22,43)$. Preliminarni rezultati najvećeg registra na području SAD-a, koji je dio ImproveCareNow mreže, govore u prilog poboljšanju ne samo njege za bolesnike, nego i ishoda liječenja, odnosno značajno je veći broj bolesnika u remisiji (44).

Trenutno još traje upis bolesnika u DEVELOP registar, u kojemu sudjeluje više od 50 centara iz SAD-a i Kanade. Riječ je o multicentričnom, prospektivnom, opservacijskom registru za djecu oboljelu od upalnih bolesti crijeva, osnovanom 2007. godine radi prikupljanja podataka o kliničkom stanju pacijenata i dugoročnoj sigurnosti primjene prvenstveno biološke, ali i drugih oblika terapije. Informacije o bolesnicima prikupljat će se na redovitim pregledima idućih 20 godina, a zacijelo će imati značajan zdravstveni i znanstveni doprinos (45).

\section{NACIONALNI REGISTAR - REPUBLIKA HRVATSKA}

S obzirom na dosadašnja pozitivna iskustva razvijenih zemalja koje imaju nacionalne registre kojima prate incidenci- ju i prevalenciju te fenotipska obilježja bolesti u svojoj zemlji, donesena je odluka o osnivanju nacionalnog registra djece oboljele od kroničnih upalnih bolesti crijeva u Republici Hrvatskoj $(\mathrm{RH})$.

Projekt će se provoditi u Referentnom centru za dječju gastroenterologiju i prehranu Klinike za dječje bolesti Zagreb u suradnji s pedijatrijskim gastroenterološkim odjelima u 4 velika centra (Zagreb, Split, Rijeka i Osijek), ali bit će uključeni i svi drugi pedijatrijski gastroenterolozi i liječnici primarne zdravstvene zaštite $u$ RH. U registar će biti uključeni svi pedijatrijski bolesnici (do 18. godine života), kojima je prema revidiranim Porto kriterijima (35) postavljena dijagnoza upalne bolesti crijeva tijekom godine dana.

\section{ZAKLJUČAK}

Upalne bolesti crijeva u djece nisu samo zdravstveni nego i veliki psihosocijalni i ekonomski problem. Nedovoljno poznavanje etiologije bolesti, dugoročne prognoze i fenotipa u djece te specifičnosti dijagnostike i terapije u pedijatrijskih bolesnika razlozi su za utemeljenje registara širom svijeta. S obzirom na izvrsne rezultate zemalja u kojima su registri već osnovani, smatramo da je osnivanje nacionalnog registra za djecu oboljelu od upalnih bolesti crijeva u RH prioritet. Izradom registra prvi će se put u $\mathrm{RH}$ utvrditi incidencija upalnih bolesti crijeva u djece, njezina fenotipska obilježja, načini dijagnostike i terapijskog pristupa, što će nedvojbeno pridonijeti boljoj organizaciji zdravstvene zaštite i kvalitetnijem zbrinjavanju bolesnika.

\section{Kratice:}

BELCRO - Registry of Pediatric Patients Diagnosed With Crohn's Disease $\mathrm{CD}$ (engl. Crohn's disease) - Crohnova bolest

ECCO - European's Crohn and Colitis Organization

EGD - ezofagogastroduodenoskopija

ESPGHAN - European Society for Paediatric Gastroenterology, Hepatology and Nutrition

EUROKIDS Registry - Europski registar za djecu oboljelu od kroničnih upalnih bolesti crijeva

IBD (engl. inflammatory bowel disease) - kronične upalne bolesti crijeva

MR enterografija - enterografija magnetskom rezonancijom

OSCCAR - Ocean State Crohn's and Colitis Registry

$\mathrm{RH}$ - Republika Hrvatska

RPIBD - Register of Paediatric IBD

SAD - Sjedinjene Američke Države

UC (engl. ulcerative colitis) - ulcerozni kolitis

\section{NOVČANA POTPORA/FUNDING}

Nema/None

\section{ETIČKO ODOBRENJE/ETHICAL APPROVAL}

Nije potrebno/None

\section{SUKOB INTERESA/CONFLICT OF INTEREST}

Autori su popunili the Unified Competing Interest form na www.icmje.org/ coi_disclosure.pdf (dostupno na zahtjev) obrazac i izjavljuju: nemaju potporu 
niti jedne organizacije za objavljeni rad; nemaju financijsku potporu niti jedne organizacije koja bi mogla imati interes za objavu ovog rada u posljednje 3 godine; nemaju drugih veza ili aktivnosti koje bi mogle utjecati na objavljeni rad./All authors have completed the Unified Competing Interest form at www.icmje.org/coi_disclosure.pdf (available on request from the corresponding author) and declare: no support from any organization for the submitted work; no financial relationships with any organizations that might have an interest in the submitted work in the previous 3 years; no other relationships or activities that could appear to have influenced the submitted work.

\section{LITERATURA}

1. Kolaček S. Primjena biološke terapije u djece s kroničnim upalnim bolestima crijeva. Acta Med Croat. 2013;67:89-92

2. de Bie $\mathrm{Cl}$, Paerregaard A, Kolacek $\mathrm{S}$, et al. Disease phenotype at diagnosis in pediatric Crohn's disease: 5-year analyses of the EUROKIDS Registry. Inflamm Bowel Dis. 2013;19:378-85. doi: 10.1002/ibd.23008.

3. Levine A, de Bie $\mathrm{Cl}$, Turner D et al. Atypical disease phenotypes in pediatric ulcerative colitis: 5 year analyses of the EUROKIDS registry. Inflamm Bowel Dis. 2013;19:370-7. doi: 10.1002/ibd.23013.

4. Mackner LM, Crandall WV. Long term psychosocial outcomes reported by children and adolescents with inflammatory bowel disease. Am J Gastroenterol. 2005;100:1386-92. doi:10.1111/j.1572-0241.2005.41428.x

5. de Bie C. Pediatric inflammatory bowel disease: from diagnosis to transition. The Netherlands: Ipskamp Drukkers BV, Enschede; 2012.

6. Dubinsky M. Special issues in pediatric inflammatory bowel disease. World J Gastroenterol. 2008;14:413-20. doi: 10.3748/wjg.14.413

7. Heyman MB, Kirschner BS, Gold BD, et al. Children with early-onset inflammatory bowel disease (IBD): analysis of a pediatric IBD consortium registry. J Pediatr. 2005;146:35-40. doi:10.1016/j.jpeds.2004.08.043

8. Benchimol El, Fortinski KJ, Gozdyra P, et al. Epidemiology of pediatric infalmmatory bowel disease: a systematic review of international trends. Inflamm Bowel Dis. 2011;17:423-39. doi: 10.1002/ibd.21349.

9. Diefenbach KA, Breuer CK. Pediatric inflammatory bowel disease. World J Gastroenterol. 2006;12:3204-12. doi: 10.3748/wjg.v12.i20.3204

10. Kugathasan S, Judd RH, Hoffmann RG, et al. Epidemiologic and clinical characteristics of children with newly diagnosed inflammatory bowel disease in Wisconsin: a statewide population-based study. J Pediatr. 2003;143:525-31. doi:10.1067/S0022-3476(03)00444-X

11. Castro M, Papadatou B, Baldassare $M$, et al. Inflammatory bowel disease in children and adolescents in Italy: data from the pediatric national IBD register (1996-2003). Inflamm Bowel Dis. 2008;14:1246-52. doi: 10.1002/ibd.20470.

12. De Greef E, Mahachie John JM, Hoffman I, et al. Profile of pediatric Crohn's disease in Belgium. J Crohns Colitis. 2013;7:e588-98. doi: 10.1016/j.crohns.2013.04.016

13. Timmer A, Behrens R, Buderus $S$, et al. Childhood onset inflammatory bowel disease: predictors of delayed diagnosis from the CEDATA German-language pediatric inflammatory bowel disease registry. J Pediatr. 2011;158:467-73. doi: 10.1016/j.jpeds.2010.09.014.

14. Dotson JL, Hyams JS, Markowitz J, et al. Extraintestinal manifestations of pediatric inflammatory bowel disease and their relation to disease type and severity. J Pediatr Gastroenterol Nutr. 2010;51:140-5. doi: 10.1097/MPG.0b013e3181ca4db4.

15. Jose FA, Garnett EA, Vittinghoff E, et al. Development of extraintestinal manifestations in pediatric patients with inflammatory bowel disease. Inflamm Bowel Dis. 2009;15:63-8. doi: 10.1002/ibd.20604.

16. Newby EA, Croft NM, Green M, et al. Natural history of paediatric inflammatory bowel diseases over a 5 -year follow-up: a retrospective review of data from the register of paediatric inflammatory bowel diseases. J Pediatr Gastroenterol Nutr. 2008;46:539-45. doi: 10.1097/MPG.0b013e3181596efd.

17. Muller KE, Lakatos PL, Arato A, et al. Incidence, Paris classification and follow-up in a nationwide incident cohort of pediatric patients with inflammatory bowel disease. J Pediatr Gastroenterol. 2013;57:576-82. doi: 10.1097/MPG.0b013e31829f7d8c

18. Goodhand J, Hedin CR, Croft NM, Lindsay JO. Adolescents with IBD: The importance of structured transition care. J Crohns Colitis. 2011;5:509-19. doi: 10.1016/j.crohns.2011.03.015.

19. Levine A, Griffiths A, Markowitz J, et al. Pediatric modification of the Montreal classification for inflammatory bowel disease: the Paris classification. Inflamm Bowel Dis. 2011;17:1314-21. doi: 10.1002/ibd.21493.

20. Silverberg MS, Satsangi J, Ahmad T, et al. Toward an integrated clinical, molecular and serological classification of inflammatory bowel disease: report of a Working Party of the 2005 Montreal World Congress of Gastroenterology. Can J Gastroenterol. 2005;19 (Suppl A):5A-36A.

21. de-Carpi MJ, Rodriguez A, Ramos E, et al. Increasing incidence of pediatric inflammatory bowel disease in Spain (1996-2009): The SPIRIT Registry. Inflamm Bowel Dis. 2013;19:73-80. doi: 10.1002/ibd.22980.

22. Jakobsen C, Paerregaard A, Munkholm P, Wewer V. Paediatric inflammatory bowel disease during a 44-year period in Copenhagen County: occurence, course and prognosis-a population based study from the Danish Crohn Colitis Database. Eur J Gastroenterol Hepatol. 2009;21:1291-301. doi: 10.1097/MEG.0b013e32832a4ed6.

23. Gower-Rousseau C, Vasseur F, Fumery M, et al. Epidemiology of inflammatory bowel diseases: New insights from a French population based registry (EPIMAD). Dig Liver Dis. 2013;45:89-94. doi: 10.1016/j.dld.2012.09.005.

24. Ishige T, Tomomasa T, Takebayashi T, et al. Inflammatory bowel disease in children: epidemiological analysis of the nationwide IBD registry in Japan. J Gastroenterol. 2010;45:911-7. doi: 10.1007/s00535-010-0223-7

25. Heyman MB, Kirschner BS, Gold BD, et al. Children with early-onset inflammatory bowel disease (IBD): analysis of a pediatric IBD consortium registry. J Pediatr. 2005;146:35-40. doi:10.1016/j.jpeds.2004.08.043

26. Keljo DJ, Markowitz J, Langton C, et al. Course and treatment of perianal disease in children newly diagnosed with Crohn's disease. Inflamm Bowel Dis. 2009;15:383-7. doi: 10.1002/ibd.20767.

27. Kovacz M, Muller KE, Arato A, et al. Diagnostic yield of upper endoscopy in paediatric patients with Crohn's disease and ulcerative colitis. Subanalysis of HUPIR Registry. J Crohns Colitis. 2012;6:86-94. doi: 10.1016/j.crohns.2011.07.008

28. Ruemmele FM, Veres $\mathrm{G}$, Kolho $\mathrm{KL}$, et al. Consensus guidelines of ECCO/ ESPGHAN on the medical management of pediatric Crohn's disease. J Crohns Colitis. 2014;8:1179-207. doi: 10.1016/j.crohns.2014.04.005.

29. Turner D, Levine A, Escher JC, et al. Management of pediatic ulcerative colitis: Joint ECCO and ESPGHAN evidence-based consensus guidelines. J Pediatr Gastroenterol Nutr. 2012;55:340-61. doi: 10.1097/MPG.0b013e3182662233

30. Jakobsen C, Paerregaard A, Munkholm P, et al. Pediatric inflammatory bowel disease: incresing incidence, decreasing surgery rate and compromised nutritional status: A prospective population-based cohort study 2007-2009. Inflamm Bowel Dis. 2011;17:2541-50. doi: 10.1002/ibd.21654.

31. Gupta N, Cohen SA, Bostrom AG, et al. Risk factors for initial surgery in pediatric patients with Crohn's disease. Gastroenterology. 2006;130:1069-77.

32. Glicklich RE, Dreyer NA, Leavy MB, editors. Registries for evaluating patients outcomes: A user's guide. $2^{\text {nd }}$ edition Rockville (MD): Agency for Healthcare Research and Quality (US ) 2010

33. Workman TA. Engaging patients in information sharing and data collection the role of patient-powered registries and research networks. American Institutes for Research Rockville (MD): Agency for Healthcare Research and Quality (US); 2013.

34. de Bie C, Buderus S, Bhupinder K, et al. Diagnostic workup of paediatric patients with inflammatory bowel disease in Europe: Results of a 5-year audit of the EUROKIDS registry. J Pediatr Gastroenterol Nutr. 2012;54:374-80. doi: 10.1097/MPG.0b013e318231d984. 
35. IBD working group of the European society for paediatric gastroenterology, hepatology and nutrition (ESPGHAN). Inflammatory bowel disease in children and adolescents: Recommendations for diagnosis-The Porto criteria. J Pediatr Gastroenterol. Nutr 2005;41:1-7

36. Levine A, Koletzko S, Turner D, et al. ESPGHAN revised Porto criteria for the diagnosis of inflammatory bowel disease in children and adolescents. J Pediatr Gastroenterol Nutr. 2014;58:795-806 doi: 10.1097/MPG.0000000000000239.

37. Sands BE, LeLeiko N, Shah SA, et al. OSCCAR: Ocean State Crohn's and Colitis Area Registry. Med Health R I. 2009;92:82-5.

38. Auvin S, Molinie F, Gower-Rousseau C, et al. Incidence, clinical presentation and location at diagnosis of pediatric inflammatory bowel disease: a prospective population-based study in northern France (1988-1999). J Pediatr Gastroenterol Nutr. 2005;41:49-55.

39. de-Carpi MJ, Rodriguez A, Ramos E, et al. The complete picture of changing pediatric inflammatory disease incidence in Spain in 25 years (1985-2009): The EXPERIENCE registry. J Crohns Colitis. 2014;8:763-9. doi: 10.1016/j.crohns.2014.01.005.

40. Chouraki V, Savoye G, Dauchet L, et al. The changing pattern of Crohn's disease incidence in northern France: a continuing increase in the 10- to 19-year-old age bracket (1988-2007). Aliment Pharmacol Ther. 2011;33:1133-42. doi: 10.1111/j.1365-2036.2011.04628.x.

41. White JM, O'Connor S, Winter HS, et al. Inflammatory bowel disease in African American children compared with other racial/ethnic groups in a multicenter registry. Clin Gastroenterol Hepatol. 2008;6:1361-9. doi: 10.1016/j.cgh.2008.07.032.

42. Virta LJ, Kolho KL. Trends in early outpatient drug therapy in pediatric inflammatory bowel disease in Finland: a nationwide register-based study in 1999-2009. ISRN Gastroenterol. 2012;2012:462642. doi: $10.5402 / 2012 / 462642$.

43. Peneau A, Savoye G, Turck D, et al. Mortality and cancer in pediatric-onset inflammatory bowel disease: a population-based study. Am J Gastroenterol 2013;108:1647-53. doi: 10.1038/ajg.2013.242.

44. Crandall W, Kappelman MD, Colletti RB, et al. ImproveCareNow: The development of a pediatric inflammatory bowel disease improvement network. Inflamm Bowel Dis. 2011;17:450-7. doi: 10.1002/ibd.21394.

45. A Multicenter, Prospective, Long-term, Observational Registry of Pediatric Patients With Inflammatory Bowel Disease (DEVELOP) https://clinicaltrials. gov/ct2/show/NCT00606346?term=develop+registry\&rank=5

\title{
The role of national registry in the care of children suffering from chronic inflammatory bowel disease
}

\author{
L. Ivković, I. Hojsak, T. Trbojević, S. Kolaček
}

Unlike adults, inflammatory bowel disease in children is marked by more extensive and severe course, affecting their future growth and development. In general, there is an increasing trend in the incidence of chronic inflammatory bowel disease, mostly on the account of Crohn's disease. Taking all these into consideration, but also the fact that inflammatory bowel disease in children occurs in a period of rapid growth and development, all pediatric patients require long-term monitoring, which is only possible through national registry. In this review, we discuss the role of national registries, their aims and methods to achieve established goals, with special reference to the importance of establishing such a registry in Croatia.

Keywords: inflammatory bowel diseases; registries; child; Croatia 